SCJR 11, no. 1 (2016): 1-2

\title{
Susan Katz Miller Being Both: Embracing Two Religions in One Interfaith Family
}

(Boston: Beacon Press, 2013), hardcover, xvii + 246 pp.

\section{MAGDALENA DZIACZKOWSKA}

dziaczkowska@gmail.com

Hochschule für Jüdische Studien Heidelberg, 69117 Heidelberg, Germany

In Being Both, journalist Susan Katz Miller advocates for and studies a grassroots movement of interfaith families in the United States who choose to raise their children in both the Jewish and Christian religions. The book is sometimes apologetic, and mainly focuses on highlighting the positive facets of a dual-faith upbringing. However, the author's point is supported by her deep knowledge of the movement due to her long engagement and lasting acquaintance with many such communities across the country. She also uses hard data collected from surveys and interviews of both parents and children who took part in dual-faith educational programs.

Miller challenges oft-raised objections to dual-faith upbringing, arguing that it is possible to celebrate both religions and traditions without diminishing either. She argues that this type of education enriches and benefits children raised in interfaith communities with dual-faith education. What distinguishes this publication from the many other books which stress the challenges of intermarriage and of raising children in interfaith families is that while it is written from a very personal perspective (Katz was an interfaith child and is now an intermarried parent), it is not only composed of personal stories. It also has a solid basis in her field study of a large group of parents who decided to raise their children in both religions as well as with teenagers and young adults who underwent such an education. This data offer a way of measuring the effects of dual-faith education on religious identity, demonstrating its positive effects on family life and link to fulfilling future religious engagement. This study is unique in that this work was written to some extent on behalf of interfaith communities in order to present the movement to a wider audience, to advocate for them, and to dispel many widespread misconceptions about interfaith families and dual-faith religious education. At the same time, the author presents a very large spectrum of ways to live both religions, from religious to secular approaches. Although she makes her own choices clear, she avoids judging others. In addition, the reader becomes familiar with the main models of interfaith communities and dual-faith education across the country. 
The book contains eleven chapters dealing with interfaith families and dual faith-education. However, it starts autobiographically, with the author's personal motivations and story. She was born to a Jewish mother and a Christian father and chose to be Jewish. She is now married to a Christian man, and they are raising their children in observance of both families' religions. She then presents a short history of the grassroots movement of interfaith families. In the following chapters, the author discusses the reasons for and benefits of "choosing both," while also presenting and responding to the challenges faced by interfaith families. After giving her own reflections on this topic, Miller gives further substance to her words by sharing numerous personal stories from intermarried parents involved in the study, as well as from Jewish and Christian clergy who serve interfaith communities. Subsequently, readers become familiar with descriptions and explanations of the major celebrations in the interfaith community and are also presented with a brief overview of interfaith curricula in dual-faith education programs. Interestingly, Miller also traces the beliefs and religious choices of interfaith adults based on a survey she administered to teenage and young adult graduates of these programs. In her discussion, she poses questions about the role of the young generation in building an open, modern society. She also points to the expected growth in interfaith families that will include Hindus, Buddhists, and Muslims, a trend that is not the main topic of the book but is closely related to it.

Thanks to the author's experience as a reporter, Being Both delivers a very well-written, engaging discourse on the issue of raising children who observe both Christianity and Judaism. Her remarks on boundary-transcending practices and beliefs might make this book suitable not only for intermarried Jews and Christians and their families, but also for those affiliated with other faiths. It offers practical insights into dual-faith education and its origins. Moreover, it is useful for future discussions, as the interfaith movement-and thus the need for educational support for parents who wish to raise their children in two religionsis growing. Some of the strongest points of this book are its clear structure and the interviews and surveys with a considerable number of parents and children from interfaith families. The only major weakness of this work might be its overly enthusiastic support for this model of interfaith families and the dual-faith educational programs designed for them. While challenges are also mentioned, they are generally minimized, and cast as a broader social refusal either to accept or to understand such choices. However, the positive tone is understandable given public resistance. Additionally, the hard data from the author's research buttresses her positive views.

This book will be helpful for general readers interested in the movement and also for researchers. While not an academic study, Being Both is a serious book introducing the ideas of dual-faith education and describing the reality of the movement of interfaith families. 